\title{
Low levels of vitamin $C$ in dialysis patients is associated with decreased prealbumin and increased C-reactive protein
}

\author{
Kunying Zhang ${ }^{1,2,3}$, Li Liu' ${ }^{1,2,3}$, Xuyang Cheng ${ }^{1,2,3}$, Jie Dong ${ }^{1,2,3}$, Qiuming Geng ${ }^{4}$ and Li Zuo 1,2,3*
}

\begin{abstract}
Background: Subclinical inflammation is a common phenomenon in patients on either continuous ambulatory peritoneal dialysis (CAPD) or maintenance hemodialysis (MHD). We hypothesized that vitamin C had antiinflammation effect because of its electron offering ability. The current study was designed to test the relationship of plasma vitamin C level and some inflammatory markers.

Methods: In this cross-sectional study, 284 dialysis patients were recruited, including 117 MHD and 167 CAPD patients. The demographics were recorded. Plasma vitamin C was measured by high-performance liquid chromatography. And we also measured body mass index (BMl, calculated as weight/height $\left.{ }^{2}\right), \mathrm{Kt} / \mathrm{N}$, serum albumin, serum prealbumin, high-sensitivity C-reactive protein (hsCRP), ferritin, hemoglobin. The relationships between vitamin $C$ and albumin, pre-albumin and hsCRP levels were tested by Spearman correlation analysis and multiple regression analysis.

Patients were classified into three subgroups by vitamin $C$ level according to previous recommendation $[1,2]$ in MHD and CAPD patients respectively: group $\mathrm{A}:<2 \mathrm{ug} / \mathrm{ml}(<11.4 \mathrm{umol} / \mathrm{l}$, deficiency), group B: $2-4 \mathrm{ug} / \mathrm{ml}$ (11.4-22.8 umol//, insufficiency) and group C: $>4 \mathrm{ug} / \mathrm{ml}$ (> $22.8 \mathrm{umol} / \mathrm{l}$, normal and above).

Results: Patients showed a widely distribution of plasma vitamin C levels in the total 284 dialysis patients. Vitamin $C$ deficiency $(<2 \mathrm{ug} / \mathrm{ml})$ was present in $95(33.45 \%)$ and insufficiency $(2-4 \mathrm{ug} / \mathrm{ml})$ in 88(30.99\%). 73(25.70\%) patients had plasma vitamin C levels within normal range $(4-14 \mathrm{ug} / \mathrm{ml})$ and $28(9.86 \%)$ at higher than normal levels (>14 ug/ml). The similar proportion of different vitamin C levels was found in both MHD and CAPD groups. Plasma vitamin C level was inversely associated with hsCRP concentration (Spearman $r=-0.201, P=0.001$ ) and positively associated with prealbumin (Spearman $r=0.268, P<0.001$ ), albumin levels (Spearman $r=0.161$, $P=0.007)$. In multiple linear regression analysis, plasma vitamin $C$ level was inversely associated with $\log _{10}$ hsCRP $(P=0.048)$ and positively with prealbumin levels $(P=0.002)$ adjusted for gender, age, diabetes, modality of dialysis and some other confounding effects.
\end{abstract}

Conclusions: The investigation indicates that vitamin C deficiency is common in both MHD patients and CAPD patients. Plasma vitamin C level is positively associated with serum prealbumin level and negatively associated with hsCRP level in both groups. Vitamin C deficiency may play an important role in the increased inflammatory status in dialysis patients. Further studies are needed to determine whether inflammatory status in dialysis patients can be improved by using vitamin $C$ supplements.

\footnotetext{
* Correspondence: zuolimd@gmail.com

${ }^{1}$ Renal Division, Department of Medicine, Peking University First Hospital,

Peking, PR China

Full list of author information is available at the end of the article
} 


\section{Background}

Because of its low molecular weight and high water solubility, vitamin $C$ could be easily cleared from plasma during dialysis $[3,4]$. As important antioxidants, vitamin $\mathrm{C}$ was prominently consumed because of oxidative stress and inflammation in patients on dialysis, which could also cause low vitamin $C$ level [5]. It is well established that plasma vitamin $C$ level was generally low in patients on dialysis $[3,6-8]$ compared with general population. In patients on dialysis, low plasma vitamin $C$ level was associated with increased risk of cardiovascular morbidity and mortality [9].

Because of the bio-incompatibility, caused by membrane-blood contact and dialysate- blood contact, there were usually excess reactive oxygen species (ROS; e.g. hydroxyl radical, hydrogen peroxide and superoxide) production $[10,11]$. Furthermore, since various proinflammatory cytokines were promoted due to metabolic acidosis [12], volume overload [13], and non-sterile dialysate [14], patients were usually on mirco-inflammation status $[15,16]$. On the other side, antioxidant levels, such as plasma vitamin $C$ level and reduced glutathione level, were usually decreased $[3,5,17,18]$. It was documented that inflammation was associated with increased risk of cardiovascular morbidity and mortality in patients on dialysis $[19,20]$.

Evidences showed that low prealbumin level was associated with worse survival in patients on dialysis [21,22]. It was also reported that inflammation caused low prealbumin level $[23,24]$. But the relationship between plasma vitamin $C$ and each of inflammatory markers and prealbumin was lacking, hence, we designed this study to pursue the relationship between vitamin $\mathrm{C}$ and inflammation.

\section{Methods}

\section{Study patients}

The study was designed as a cross-sectional analysis including both MHD patients and CAPD patients in Peking University First Hospital. Patients aged between 18 and 80 years and could provide informed consent were included. Patients who had autoimmune disease, malignancy, hepatitis in active conditions, currently used steroids or immune-suppressants, had positive human immunodeficiency virus(HIV) serology, and had any kind of acute infection within one month were excluded. However, patients having stable cardiovascular disease, or using central venous catheter, using angiotensin converting enzyme inhibitor (ACEI), angiotensin receptor antagonist (ARB), or statins were not excluded.

MHD patients were dialyzed three times per week, 4-4.5 hours per session, among them, 54 patients were treated with conventional hemodialysis (HD), 51 with high-flux hemodialysis (HFD), and 12 with hemodiafiltration (HDF).
CAPD patients received 3-4 daily exchanges of $2 \mathrm{~L}$ of peritoneal dialysis solution with either $1.5 \%$ or $2.5 \%$ glucose.

MHD and CAPD patients were classified by vitamin C level into three subgroups, respectively, according to previous recommendation $[1,2]$ : group $\mathrm{A}$, or vitamin $\mathrm{C}$ deficiency group, had vitamin $\mathrm{C}<2 \mathrm{ug} / \mathrm{ml}$; group $\mathrm{B}$, or vitamin $C$ insufficiency group, had vitamin $C$ level between $2-4 \mathrm{ug} / \mathrm{ml}$ and group $\mathrm{C}$, or vitamin $\mathrm{C}$ normal or above the normal group, had vitamin $\mathrm{C}>4 \mathrm{ug} / \mathrm{ml}$.

This study was approved by the local ethics committee and written informed consent was obtained from each participant.

\section{Sample collection and laboratory procedures}

Blood samples for vitamin $C$ determination were drawn from the arteriovenous fistula just before dialysis session in MHD patients, and from a forearm vein in CAPD patients. All subjects were in fasting condition. Blood was collected into heparin-containing tube, and then was transported in an ice bath to the laboratory. Plasma was separated by centrifugation $(2000 \times \mathrm{g}, 10 \mathrm{~min})$ at $4^{\circ} \mathrm{C}$ within 30 minutes, an aliquot of 200 ul plasma was mixed with $200 \mathrm{ul}$ of $10 \%$ metaphosphoric acid (MPA) and stored at $-80^{\circ} \mathrm{C}$ until analysis within 2 weeks.

Vitamin $\mathrm{C}$ was determined by high-performance liquid chromatography (HPLC) (Agilent 1100 series, Agilent Technologies, USA) on a Diamonsil C18 column $(150 \mathrm{~mm} \times 4.6 \mathrm{~mm}, 3 \mathrm{um})$ at $25^{\circ} \mathrm{C}$. For HPLC analysis, the thawed plasma with MPA was centrifuged at $22000 \mathrm{~g}$ for $10 \mathrm{~min}, 4^{\circ} \mathrm{C}, 20 \mathrm{ul}$ supernatants was injected into the HPLC by an autosampler. The mobile phase consisted of $25 \mathrm{mM}$ sodium dihydrogenphosphate $\mathrm{pH}$ 2.6 , the flow rate was $0.5 \mathrm{~mL} / \mathrm{min}$, and observed wavelength was $244 \mathrm{~nm}$. Intra-assay and inter-assay coefficients of variation were $2.7 \%$ and $2.5 \%$, respectively. The reference range of vitamin $C$ level in normal population for this assay was $4-14 \mathrm{mg} / \mathrm{L}[1,2]$.

Prealbumin, high-sensitivity C-reactive protein (hsCRP), albumin, ferritin, calcium, serum bicarbonate, uric acid and hemoglobin were measured by standard techniques (the Clinical Laboratory of Peking University First Hospital, Beijing, China).

\section{Statistical Analysis}

The relationships between vitamin $\mathrm{C}$ and each of albumin, prealbumin and hsCRP levels were tested using Spearman correlation analysis. Levels of each of vitamin $\mathrm{C}$, hsCRP, albumin, prealbumin, uric acid, and hemoglobin were compared between MHD and CAPD patients using t-test. The above parameters were also compared using one-way analysis of variance (1-way-ANOVA) among groups $\mathrm{A}, \mathrm{B}$ and $\mathrm{C}$ in each of MHD and CAPD patients, respectively. Using each of prealbumin, albumin and $\log _{10}$ hsCRP as outcome and vitamin $C$ as 
predictor, three linear regression model were constructed to explore the relationship between categories of plasma vitamin $\mathrm{C}$ level $(<2 \mathrm{ug} / \mathrm{ml}, 2-4 \mathrm{ug} / \mathrm{ml}$ and $>4 \mathrm{ug} / \mathrm{ml}$ ) and each of prealbumin, albumin and $\log _{10}$ hsCRP after gender, age, diabetes, modality of dialysis and other confounding effects were adjusted. Numeric parameters were assessed by $\chi^{2}$ test. Median, range, percentiles and Kruskal Wallis Test were used for non-normally distributed variables. Statistical analysis was performed using SPSS version11.5 (SPSS, Inc., Chicago, IL, USA). P values $<0.05$ were considered as statistically significant.

\section{Results}

\section{Demographics}

The demographics of all the included patients were listed in table 1 . There were 117 MHD patients and 167 CAPD patients, with a mean age of $59.8 \pm 13.8$ years and a mean dialysis vintage of $41.8 \pm 37.2$ months (median 32, range 1-233).

The primary causes of end stage of renal disease (ESRD) were chronic glomerulonephritis $(\mathrm{n}=93)$, diabetic nephropathy $(\mathrm{n}=57)$, interstitial nephropathy $(n=45)$, hypertensive nephrosclerosis $(n=33)$, polycystic disease $(n=10)$, lupus nephropathy $(n=2)$, chronic pyelonephritis $(n=1)$, and others $(n=43)$.

Compared with CAPD patients, MHD patients had lower prealbumin, lower serum bicarbonate, higher albumin,

\section{Table 1 Baseline characteristics of the study population} ( $\mathrm{n}=\mathbf{2 8 4}$ )

\begin{tabular}{|c|c|c|c|}
\hline Parameters & $\begin{array}{l}\text { MHD patients } \\
\quad(n=117)\end{array}$ & $\begin{array}{l}\text { CAPD patients } \\
\quad(n=167)\end{array}$ & $\begin{array}{c}P \\
\text { value }\end{array}$ \\
\hline Age(year) & $59.3 \pm 13.9$ & $60.2 \pm 13.7$ & 0.594 \\
\hline Gender & & & 0.540 \\
\hline Male & $45(38.46 \%)$ & $71(42.52 \%)$ & \\
\hline Female & $72(61.54 \%)$ & $96(57.48 \%)$ & \\
\hline $\mathrm{BMI}$ & $22.7 \pm 4.3$ & $23.5 \pm 3.2$ & 0.071 \\
\hline Diabetes & 9/117(7.7\%) & 48/167(28.7\%) & 0.000 \\
\hline Prealbumin(mg/l) & $285.8 \pm 77.3$ & $371.7 \pm 94.3$ & 0.000 \\
\hline Albumin(g/l) & $38.9 \pm 3.9$ & $36.0 \pm 4.2$ & 0.000 \\
\hline Uric acid(umol/l) & $381.2 \pm 82.9$ & $376.6 \pm 79.8$ & 0.642 \\
\hline Haemoglobin(g/l) & $110.0 \pm 17.2$ & $109.5 \pm 12.3$ & 0.806 \\
\hline $\begin{array}{l}\text { bicarbonate } \\
(\mathrm{mmol} / \mathrm{l})\end{array}$ & $22.0 \pm 3.6$ & $25.7 \pm 3.2$ & 0.000 \\
\hline \multirow[t]{2}{*}{$\mathrm{SBP}(\mathrm{mmHg})$} & $145.1 \pm 19.8$ & $128.9 \pm 17.7$ & 0.000 \\
\hline & Median(IQR) & Median(IQR) & \\
\hline Vitamin C(ug/ml) & $2.9(1.6-5.5)$ & $3.0(1.8-5.0)$ & 0.549 \\
\hline $\mathrm{hsCRP}(\mathrm{mg} / \mathrm{l})$ & $2.6(1.0-6.5)$ & $2.8(1.0-8.2)$ & 0.756 \\
\hline Ferritin(ng/ml) & $377(246.9-634.1)$ & $374(215-585)$ & 0.530 \\
\hline $\begin{array}{l}\text { Dialysis vintage } \\
\text { (m) }\end{array}$ & $49(20-88)$ & $24(9-49)$ & 0.000 \\
\hline
\end{tabular}

Abbreviation: BMI: body mass index; SBP: systolic blood pressure; IQR: inter quartile range; hsCRP: high-sensitivity $C$-reactive protein. higher systolic blood pressure and longer dialysis vintage. No statistical significance was found in age, gender and body mass index between CAPD and MHD patients.

\section{Distribution of plasma vitamin C}

Patients showed a widely distribution of plasma vitamin $\mathrm{C}$ levels. The median plasma level was $3.34 \mathrm{ug} / \mathrm{ml}$ and the range from the 25 th to the 75 th percentile [inter quartile range (IQR)] was 1.87-5.74 ug/ml. vitamin C deficiency was present in $95(33.45 \%)$ and insufficiency in $88(30.99 \%)$ of the dialysis patients. $73(25.70 \%)$ patients had plasma vitamin $\mathrm{C}$ levels within normal range and $28(9.86 \%)$ at higher than normal levels. There were 48 patients taking vitamin $\mathrm{C}$ supplements (median $100 \mathrm{mg} /$ day, range 50-600 mg/day), among whom, 9 patients with daily vitamin $C$ supplement 50 to $100 \mathrm{mg}$ had plasma vitamin $\mathrm{C}$ level less than $4 \mathrm{ug} / \mathrm{ml}$, and 26 patients with daily vitamin $C$ supplement $300 \mathrm{mg}$ or more had higher plasma vitamin $\mathrm{C}$ level than normal.

\section{Association of vitamin C and prealbumin, albumin, hsCRP} In the total dialysis patients, plasma vitamin $C$ level was positively associated with prealbumin (Spearman $r=0.268$, $\mathrm{P}<0.001$ ), albumin (Spearman $\mathrm{r}=0.161, \mathrm{P}=0.007$ ), and inversely associated with hsCRP (Spearman $r=-0.201$, $\mathrm{P}=0.001)$, age (Spearman $\mathrm{r}=-0.233, \mathrm{P}=0.000$ ). Prealbumin is negatively correlated with hsCRP (Spearman $\mathrm{r}=-0.331, \mathrm{P}<0.01)$. No significant association was found between vitamin $\mathrm{C}$ and each of gender, hemoglobin, $\mathrm{KT} / \mathrm{V}$, body mass index, ferritin, or dialysis vintage in our study.

In MHD group, compared with group $\mathrm{A}$, groups $\mathrm{B}$ and $C$ had significantly lower age, higher albumin, higher prealbumin, and lower hsCRP (table 2) while gender, body mass index, $\mathrm{KT} / \mathrm{V}$ and dialysis vintage were comparable among the three subgroups (table 2). The similar trend was found in CAPD patients (table 2).

Patients receiving HDF treatment had lower $\log _{10}$ hsCRP value $(0.04 \pm 0.71)$ compared with patients receiving HD treatment $(0.52 \pm 0.64, \mathrm{P}=0.03)$. There was no statistical significance in each of plasma vitamin $C$ level, albumin and prealbumin among three MHD modalities.

Compared with patients without oral vitamin $\mathrm{C}$ supplements, patients with vitamin $C$ supplements had increased $\operatorname{albumin}(38.47 \pm 3.28 \mathrm{~g} / \mathrm{L}$ vs $37.00 \pm 4.44 \mathrm{~g} / \mathrm{L}, \mathrm{P}=0.04)$, not significantly high prealbumin $(341.08 \pm 65.39 \mathrm{mg} / \mathrm{L}$ vs $336.83 \pm 101.74 \mathrm{mg} / \mathrm{L}, \mathrm{P}=0.79)$, and not significantly low $\log _{10}$ hsCRP(0.28 \pm 0.65 vs $\left.0.41 \pm 0.69, \mathrm{P}=0.21\right)$.

\section{Multivariate analysis for vitamin C effects on prealbumin and hsCRP levels}

In the whole dialysis patients, after adjusting for gender, age, diabetes and modality of dialysis, systolic blood pressure, metabolic acidosis and use of statins, per 
Table 2 Clinical characteristics of three subgroups according to different vitamin C levels in MHD and CAPD groups

\begin{tabular}{|c|c|c|c|c|c|c|}
\hline \multirow[b]{2}{*}{ Parameters } & \multicolumn{3}{|c|}{ MHD group } & \multicolumn{3}{|c|}{ CAPD group } \\
\hline & $\begin{array}{c}\text { group } A \\
<2 \mathrm{ug} / \mathrm{ml}(\mathrm{n}=44)\end{array}$ & $\begin{array}{c}\text { group B } \\
2-4 \mathrm{ug} / \mathrm{ml}(\mathrm{n}=32)\end{array}$ & $\begin{array}{c}\text { group C } \\
>4 \mathrm{ug} / \mathrm{ml}(\mathrm{n}=41)\end{array}$ & $\begin{array}{c}\text { group A } \\
<2 \mathrm{ug} / \mathrm{ml}(\mathrm{n}=51)\end{array}$ & $\begin{array}{c}\text { group B } \\
2-4 \mathrm{ug} / \mathrm{ml}(\mathrm{n}=56)\end{array}$ & $\begin{array}{c}\text { group C } \\
>4 \mathrm{ug} / \mathrm{ml}(\mathrm{n}=60)\end{array}$ \\
\hline Age(year) & $66.4 \pm 11.3$ & $55.6 \pm 12.8^{a}$ & $54.5 \pm 14.5^{a}$ & $64.9 \pm 11.4$ & $57.8 \pm 13.7^{\mathrm{a}}$ & $58.4 \pm 14.6^{b}$ \\
\hline Gender(male/female) & 20/24 & 13/19 & $12 / 29$ & $26 / 25$ & 23/33 & $22 / 38$ \\
\hline BMl & $22.6 \pm 4.5$ & $22.9 \pm 4.4$ & $22.5 \pm 4.0$ & $24.0 \pm 3.3$ & $23.0 \pm 2.9$ & $23.6 \pm 3.3$ \\
\hline $\mathrm{KT} N$ & $1.6 \pm 0.3$ & $1.6 \pm 0.3$ & $1.7 \pm 0.2$ & $1.8 \pm 0.4$ & $1.9 \pm 0.3$ & $1.9 \pm 0.4$ \\
\hline Diabetes & $5 / 39$ & $1 / 31$ & $3 / 38$ & $17 / 34$ & 18/38 & $13 / 47$ \\
\hline Vitamin C(ug/ml) & $1.2 \pm 0.5$ & $2.9 \pm 0.6^{a}$ & $17.9 \pm 20.4^{a c}$ & $1.4 \pm 0.4$ & $3.0 \pm 0.6^{a}$ & $10.0 \pm 10.6^{a c}$ \\
\hline Prealbumin(mg/l) & $250.5 \pm 77.2$ & $305.0 \pm 72.3^{a}$ & $309.2 \pm 68.0^{a}$ & $337.7 \pm 83.7$ & $371.6 \pm 85.7^{b}$ & $400.2 \pm 102.1^{a}$ \\
\hline $\mathrm{hsCRP}(\mathrm{mg} / \mathrm{l})$ & $3.7(1.5-11.6)$ & $1.8(0.7-6.3)^{b}$ & $2.0(0.4-5.1)^{b}$ & $4.2(1.9-14.8)$ & $2.1(0.9-6.3)^{b}$ & $2.1(0.9-5.2)^{b}$ \\
\hline Albumin(g/l) & $37.4 \pm 4.1$ & $40.6 \pm 3.8^{a}$ & $39.3 \pm 3.1^{b}$ & $34.7 \pm 4.6$ & $36.8 \pm 3.5^{\mathrm{a}}$ & $36.3 \pm 4.2^{\mathrm{b}}$ \\
\hline Uric acid(umol/l) & $380.3 \pm 77.2$ & $397.6 \pm 87.4$ & $368.9 \pm 82.8$ & $358.1 \pm 86.3$ & $380.8 \pm 68.6$ & $388.4 \pm 82.2^{b}$ \\
\hline Haemoglobin(g/l) & $107.5 \pm 18.7$ & $117.5 \pm 15.0^{b}$ & $106.7 \pm 15.7^{c}$ & $109.4 \pm 13.9$ & $110.8 \pm 11.8$ & $108.4 \pm 11.5$ \\
\hline Ferritin(ng/ml) & $412.7 \pm 247.2$ & $397.2 \pm 209.4$ & $524.5 \pm 386.4$ & $508.2 \pm 330.7$ & $372.0 \pm 294.3^{b}$ & $427.6 \pm 309.3$ \\
\hline Dialysis vintage(m) & $64.0 \pm 48.2$ & $55.3 \pm 37.8$ & $53.3 \pm 46.0$ & $27.4 \pm 23.1$ & $31.1 \pm 26.3$ & $32.6 \pm 26.5$ \\
\hline
\end{tabular}

${ }^{\mathrm{a}} \mathrm{P}<0.01$ : compared with group $\mathrm{A} ;{ }^{\mathrm{b}} \mathrm{P}<0.05$ :compared with group $\mathrm{A} ;{ }^{\mathrm{c}} \mathrm{P}<0.01$ : compared with group $\mathrm{B}$.

category increase of vitamin $C$ caused $0.098 \pm 0.049$ decrement of $\log _{10}$ (hsCRP), this corresponding to 1.25 $(1.12,1.40) \mathrm{mg} / \mathrm{L}$ decrement of hsCRP $(\mathrm{P}=0.048)$, (table 3).

Plasma vitamin $\mathrm{C}$ was positively with prealbumin levels $(\mathrm{P}=0.002)$ adjusted for hsCRP and above cofactors, prealbumin level was $58.49 \pm 12.29 \mathrm{mg} / \mathrm{L}$ lower in patients with vitamin $\mathrm{C}$ deficiency compared with patients with normal vitamin $\mathrm{C}$ level.

However, there was no statistical significant association between plasma vitamin $\mathrm{C}$ and albumin (table 3).

\section{Discussion}

In the present study, it was found that vitamin $\mathrm{C}$ deficiency and insufficiency was a great problem in our dialysis patients. The results showed that lower plasma vitamin $C$ level was associated with lower prealbumin and higher hsCRP concentration both in MHD and in CAPD patients. These findings collectively suggest that vitamin $\mathrm{C}$ deficiency could be associated with the higher clinical inflammatory status in our patients.

Patients with active autoimmune disease, malignancy, hepatitis and acute infection were excluded, because these kinds of conditions could cause acute oxidative stress and acute change of hsCRP and vitamin C. Patients with stable cardiovascular disease, using central venous catheter, or on regular medication of ACEI, ARB or statins were not excluded, because we thought these conditions could not change the relationship between hsCRP and vitamin C.

We found in both MHD and CAPD groups plasma vitamin $C$ level was inversely associated with age, patients with plasma vitamin $\mathrm{C}<2 \mathrm{ug} / \mathrm{ml}$ (group A) had older age. And we also found higher hsCRP, lower albumin and lower prealbumin in such patients, in common with the results of some previous studies $[25,26]$. These results may due to a decreasing intake [27], and an increasing oxidative stress with ageing [28-30].

Numerous studies reported that low plasma level of vitamin $C$ in dialysis patients is commonly found owing to loss during dialysis procedure, inadequate dietary intake, reduced tubular reabsorption and impaired metabolism [3,7,31-33], which was in consistent with our investigation.

Several clinical studies suggested a linkage between oxidative stress and inflammation in uremic individuals, but few had focused on the relationship between vitamin $\mathrm{C}$ status and inflammatory indicators, and, if analyzed, statistical relationship between vitamin $C$ and each of hsCRP and prealbumin were not obtained in those previous investigations $[4,34,35]$. What we revealed in our study did not parallel these observations. One important reason is that most of the previous study patients had daily oral vitamin $C$ supplementation during those investigations, which could change the inflammatory status. Second, differences in age, smoking status, dialysis vintage and proportion of diabetes in the study populations may be responsible for the different results.

We proposed that the association between vitamin C and inflammation markers observed in our study was explained by that inflammation and oxidative stress have certain internal relations. The oxidative products such as superoxide anion $\left(\mathrm{O}_{2}{ }^{-}\right)$and hydrogen peroxide $\left(\mathrm{H}_{2} \mathrm{O}_{2}\right)$ during dialysis procedure could trigger inflammation in uremic patients [10]. On the contrary, oxidative stress may be further aggravated by inflammation through potentiating respiratory burst activation in 
Table 3 Association between plasma Vitamin C level and each of prealbumin, hsCRP and albumin levels adjusted for cofounders in multiple linear regressions

\begin{tabular}{|c|c|c|c|c|c|c|}
\hline & \multirow[t]{2}{*}{ variable } & \multirow[t]{2}{*}{ Beta } & \multicolumn{2}{|c|}{$95 \% \mathrm{Cl}$} & \multirow{2}{*}{$\begin{array}{l}\mathrm{t} \\
\text { value }\end{array}$} & \multirow{2}{*}{$\begin{array}{c}P \\
\text { value }\end{array}$} \\
\hline & & & lower & upper & & \\
\hline \multirow[t]{9}{*}{ prealbumin } & $\begin{array}{l}\text { VitC(per category } \\
\text { increase) }\end{array}$ & 0.155 & 7.021 & 29.477 & 3.186 & 0.002 \\
\hline & age & -0.243 & -66.011 & -28.674 & -4.970 & 0.000 \\
\hline & Diabetes & -0.162 & -63.307 & -15.387 & -3.219 & 0.001 \\
\hline & gender & 0.125 & 5.590 & 44.194 & 2.528 & 0.012 \\
\hline & modality & 0.424 & 39.327 & 66.793 & 7.573 & 0.000 \\
\hline & hsCRP(mg/l) & -0.255 & -2.888 & -1.337 & -5.340 & 0.000 \\
\hline & $\begin{array}{l}\text { bicarbonate } \\
(\mathrm{mmol} / \mathrm{l})\end{array}$ & -0.038 & -3.561 & 1.613 & -0.738 & 0.461 \\
\hline & $\mathrm{SBP}(\mathrm{mmHg})$ & 0.030 & -0.335 & 0.627 & 0.594 & 0.553 \\
\hline & statins & 0.175 & 17.612 & 59.441 & 3.611 & 0.000 \\
\hline \multirow[t]{8}{*}{$\log _{10}$ hsCRP } & $\begin{array}{l}\text { VitC(per category } \\
\text { increase) }\end{array}$ & -0.117 & -0.195 & -0.001 & -1.984 & 0.048 \\
\hline & age & 0.295 & 0.249 & 0.569 & 5.023 & 0.000 \\
\hline & Diabetes & -0.009 & -0.224 & 0.192 & -0.152 & 0.879 \\
\hline & gender & 0.089 & -0.042 & 0.293 & 1.472 & 0.142 \\
\hline & modality & -0.071 & -0.182 & 0.057 & -1.030 & 0.304 \\
\hline & $\begin{array}{l}\text { bicarbonate } \\
(\mathrm{mmol} / \mathrm{l})\end{array}$ & -0.081 & -0.037 & 0.008 & -1.295 & 0.196 \\
\hline & $\mathrm{SBP}(\mathrm{mmHg})$ & -0.220 & -0.012 & -0.003 & -3.581 & 0.000 \\
\hline & statins & 0.025 & -0.142 & 0.220 & 0.421 & 0.674 \\
\hline \multirow[t]{8}{*}{ albumin } & $\begin{array}{l}\text { VitC(per category } \\
\text { increase) }\end{array}$ & 0.065 & -0.246 & 0.928 & 1.138 & 0.256 \\
\hline & age & -0.252 & -3.138 & -1.214 & -4.432 & 0.000 \\
\hline & Diabetes & -0.214 & -3.548 & -1.035 & -3.575 & 0.000 \\
\hline & gender & -0.013 & -1.127 & 0.900 & -0.219 & 0.827 \\
\hline & modality & -0.176 & -1.699 & -0.252 & -2.641 & 0.009 \\
\hline & $\begin{array}{l}\text { bicarbonate } \\
(\mathrm{mmol} / \mathrm{l})\end{array}$ & -0.085 & -0.232 & 0.040 & -1.381 & 0.168 \\
\hline & $\mathrm{SBP}(\mathrm{mmHg})$ & 0.099 & -0.004 & 0.046 & 1.659 & 0.098 \\
\hline & statins & 0.097 & -0.148 & 2.026 & 1.694 & 0.091 \\
\hline
\end{tabular}

Abbreviation: Vit C: vitamin C; SBP: systolic blood pressure.

VitC(by categories) deficiency 1, insufficiency 2, normal and above 3; Age(by categories) < 60y 0, 260y 1; Diabetes: non- Diabetes 0, Diabetes 1; gender: F $0, M 1$; modality: HD 1, HDF 2, HFD 3, CAPD 4; statins: without statins 0 , with statins 1.

monocytes and neutrophils [18]. Some investigations proved that hsCRP had a close correlation with thiobarbituric acid reactive substances(TBARS) [5], a marker of lipid peroxidation, and $\alpha$-tocopherol, and inflammatory proteins comprised $\mathrm{C}$-reactive protein, fibrinogen and $\alpha 1$-antitrypsin were significantly correlated with most markers of oxidative stress [36]. Jenny $M$ et al [37] found that acute administration of vitamin $C$ reduced oxidant stress levels and improved NO-mediated resistance vessel dilatation in renal failure. Kamgar $\mathrm{M}$ at al [38] also showed that MHD patients had a decrease trend in C-reactive protein compared with the baseline after given oral vitamin $C$ supplement for 8 weeks although it did not get statistical significance. However, Fumeron $\mathrm{C}$ et al [39] in a small-scale prospective study included 33 MHD patients (19 patients with oral vitamin C $250 \mathrm{mg}$ three times per week after dialysis sessions, 14 patients without oral vitamin C) did not reveal that vitamin $\mathrm{C}$ could ameliorate oxidative stress and inflammation within 2 months.

Prealbumin is a negative acute-phase protein synthesized primarily by the liver [40], its plasma level reflects the presence of an ongoing or resolving inflammatory condition just as well as $\mathrm{C}$-reactive protein. Prealbumin serum concentrations may have parallel changes with protein and energy intakes [41] and inverse changes in inflammation [42], it was somewhat equally considered as both markers of nutritional status and inflammation. Mehdi Rambod et al [21] reported in a 798 MHD patients cohort study, prealbumin inversely correlated with hsCRP and Interleukin-6 (IL-6), the surrogates of inflammation, which is very much like our observations.

Lee EJ et al [43] reported that plasma vitamin C levels positively related to albumin with Serum ascorbic acid $<$ or $=9 \mathrm{mg} / \mathrm{L}$. In the present investigation, we also found plasma vitamin $C$ positively related with albumin in Spearman correlation analysis, but the association did not exist after adjustment for sex, age, diabetes, mode of dialysis and other confounding effects. Several recent documents investigated that plasma vitamin $C$ levels closely associated with hemoglobin [34], iPTH and alkaline phosphatase [1]. However, we did not get such findings in both univariate and multivariate analysis in our sample, which maybe partly explained by the different selective standard of study population.

Previous study demonstrated that the elimination of plasma vitamin $\mathrm{C}$ is similar in both conventional hemodialysis and on-line hemodiafiltration [44], which is in line with our findings. In our study, there was no difference in plasma vitamin $C$ level among the three MHD modalities. These results may be due to its small molecule $(176.1 \mathrm{Da})$, highly soluble characteristic in water and low protein-bound. Patients receiving HDF treatment had lower $\log _{10}$ hsCRP value compared with patients receiving HD treatment in our investigation, this observation was in consistent with some other previous results $[45,46]$.

\section{Conclusion}

In conclusion, our cross-sectional observation indicated that vitamin $\mathrm{C}$ deficiency was prevalent in dialysis patients, and lower plasma vitamin $C$ level was associated with lower serum prealbumin and higher hsCRP concentration which may be closely link to oxidative stress and inflammation in uremia. Further large-scale, long-term interventional clinical trials are required to 
validate if vitamin $C$ supplementation can reduce inflammatory process and improve outcome of dialysis patients.

\section{Author details}

${ }^{1}$ Renal Division, Department of Medicine, Peking University First Hospital, Peking, PR China. ${ }^{2}$ Peking University Institute of Nephrology, Peking, PR China. ${ }^{3}$ Key Laboratory of Renal Disease, Beijing, PR China. ${ }^{4}$ Central Lab, Peking University Third Hospital; Beijing, 100034 PR China.

\section{Authors' contributions}

KYZ participated in the design of the study, sampling procedure, and drafted the manuscript. LL participated in the design of the study and sampling procedure. XYC participated in the design of the study. JD participated in the design of the study. QMG participated in sampling procedure and performed some statistical analysis. LZ conceived the study, and participated in its design and coordination and performed statistical analysis. All authors read and approved the final manuscript.

\section{Competing interests}

The authors declare that they have no competing interests.

Received: 8 December 2010 Accepted: 6 May 2011

Published: 6 May 2011

\section{References}

1. Richter A, Kuhlmann MK, Seibert E, Kotanko P, Levin NW, Handelman GJ: Vitamin C deficiency and secondary hyperparathyroidism in chronic haemodialysis patients. Nephrol Dial Transplant 2008, 23(6):2058-2063.

2. Reuler JB, Broudy VC, Cooney TG: Adult scurvy. JAMA 1985, 253(6):805-807.

3. Morena M, Cristol JP, BosC JY, Tetta C, Forret G, Leger CL, Delcourt C, Papoz L, Descomps B, Canaud B: Convective and diffusive losses of vitamin $C$ during haemodiafiltration session: a contributive factor to oxidative stress in haemodialysis patients. Nephrol Dial Transplant 2002, 17(3):422-427.

4. Sundl I, Roob JM, Meinitzer A, Tiran B, Khoschsorur G, Haditsch B, Holzer H, Winklhofer-Roob BM: Antioxidant status of patients on peritoneal dialysis: associations with inflammation and glycoxidative stress. Perit Dial Int 2009, 29(1):89-101.

5. Nguyen-Khoa T, Massy ZA, De Bandt JP, Kebede M, Salama L, Lambrey G, Witko-Sarsat V, Drueke TB, Lacour B, Thevenin M: Oxidative stress and haemodialysis: role of inflammation and duration of dialysis treatment. Nephrol Dial Transplant 2001, 16(2):335-340.

6. Wang S, Eide TC, Sogn EM, Berg KJ, Sund RB: Plasma ascorbic acid in patients undergoing chronic haemodialysis. Eur I Clin Pharmacol 1999, 55(7):527-532.

7. Boeschoten EW, Schrijver J, Krediet RT, Schreurs WH, Arisz L: Deficiencies of vitamins in CAPD patients: the effect of supplementation. Nephrol Dial Transplant 1988, 3(2):187-193.

8. Singer R, Rhodes HC, Chin G, Kulkarni H, Ferrari P: High prevalence of ascorbate deficiency in an Australian peritoneal dialysis population. Nephrology (Carlton) 2008, 13(1):17-22

9. Deicher R, Ziai F, Bieglmayer C, Schillinger M, Horl WH: Low total vitamin C plasma level is a risk factor for cardiovascular morbidity and mortality in hemodialysis patients. J Am Soc Nephrol 2005, 16(6):1811-1818.

10. Yoon JW, Pahl MV, Vaziri ND: Spontaneous leukocyte activation and oxygen-free radical generation in end-stage renal disease. Kidney Int 2007, 71(2):167-172.

11. Srinivasa RP, Dakshinamurty KV, Saibaba KS, Sheela RB, Venkataramana G, Sreekrishna V, Ambekar JG, Jayaseelan L: Oxidative stress in haemodialysis: immediate changes caused by passage of blood through the dialyser. Ann Clin Biochem 2001, 38(Pt 4):401-405.

12. Bellocq A, Suberville S, Philippe C, Bertrand F, Perez J, Fouqueray B, Cherqui G, Baud L: Low environmental pH is responsible for the induction of nitric-oxide synthase in macrophages. Evidence for involvement of nuclear factor-kappaB activation. J Biol Chem 1998, 273(9):5086-5092.

13. Demirci MS, Demirci C, Ozdogan O, Kircelli F, Akcicek F, Basci A, Ok E, Ozkahya M: Relations between malnutrition-inflammation-atherosclerosis and volume status. The usefulness of bioimpedance analysis in peritoneal dialysis patients. Nephrol Dial Transplant 2010.

14. Stenvinkel P, Alvestrand A: Inflammation in end-stage renal disease: sources, consequences, and therapy. Semin Dial 2002, 15(5):329-337.

15. Ho LC, Wang HH, Chiang CK, Hung KY, Wu KD: Malnutrition-inflammation score independently determined cardiovascular and infection risk in peritoneal dialysis patients. Blood Purif 2010, 30(1):16-24.

16. Kalantar-Zadeh K, Ikizler TA, Block G, Avram MM, Kopple JD: Malnutritioninflammation complex syndrome in dialysis patients: causes and consequences. Am J Kidney Dis 2003, 42(5):864-881.

17. Zwolinska D, Grzeszczak W, Szczepanska M, Makulska I, Kilis-Pstrusinska K, Szprynger K: Oxidative stress in children on peritoneal dialysis. Perit Dial Int 2009, 29(2):171-177.

18. Zeller JM, Sullivan BL: C-reactive protein selectively enhances the intracellular generation of reactive oxygen products by $\mathrm{lgG}$-stimulated monocytes and neutrophils. J Leukoc Biol 1992, 52(4):449-455.

19. Zimmermann J, Herrlinger S, Pruy A, Metzger T, Wanner C: Inflammation enhances cardiovascular risk and mortality in hemodialysis patients. Kidney Int 1999, 55(2):648-658.

20. Paniagua R, Frias $Y$, de Ventura MJ, Rodriguez E, Hurtado ME, Alcantara G, Vazquez R, Ortiz R, Salcedo M, Rios ME, et al: C-reactive protein and antiChlamydia pneumoniae antibodies as risk factors of cardiovascular death in incident patients on peritoneal dialysis. Perit Dial Int 2003, 23(2):132-137.

21. Rambod M, Kovesdy CP, Bross R, Kopple JD, Kalantar-Zadeh K: Association of serum prealbumin and its changes over time with clinical outcomes and survival in patients receiving hemodialysis. Am J Clin Nutr 2008 , 88(6):1485-1494.

22. Pupim LB, Caglar K, Hakim RM, Shyr Y, Ikizler TA: Uremic malnutrition is a predictor of death independent of inflammatory status. Kidney Int 2004, 66(5):2054-2060.

23. Ikizler TA, Wingard RL, Harvell J, Shyr Y, Hakim RM: Association of morbidity with markers of nutrition and inflammation in chronic hemodialysis patients: a prospective study. Kidney Int 1999, 55(5):1945-1951.

24. Hrnciarikova D, Juraskova B, Hyspler R, Solichova D, Ticha A, Klemera P, Hronek M, Zadak Z: A changed view of serum prealbumin in the elderly: prealbumin values influenced by concomitant inflammation. Biomed Pap Med Fac Univ Palacky Olomouc Czech Repub 2007, 151(2):273-276.

25. Forster S, Gariballa S: Age as a determinant of nutritional status: a cross sectional study. Nutr J 2005, 4:28.

26. Simon JA: Vitamin C and cardiovascular disease: a review. J Am Coll Nutr 1992, 11(2):107-125.

27. Burr ML, Milbank JE, Gibbs D: The nutritional status of the elderly. Age Ageing 1982, 11(2):89-96.

28. Rebrin I, Kamzalov S, Sohal RS: Effects of age and caloric restriction on glutathione redox state in mice. Free Radic Biol Med 2003, 35(6):626-635.

29. Finkel T, Holbrook NJ: Oxidants, oxidative stress and the biology of ageing. Nature 2000, 408(6809):239-247.

30. Toroser D, Sohal RS: Age-associated perturbations in glutathione synthesis in mouse liver. Biochem J 2007, 405(3):583-589.

31. Alkhunaizi AM, Chan L: Secondary oxalosis: a cause of delayed recovery of renal function in the setting of acute renal failure. J Am Soc Nephrol 1996, 7(11):2320-2326.

32. Durose CL, Holdsworth M, Watson V, Przygrodzka F: Knowledge of dietary restrictions and the medical consequences of noncompliance by patients on hemodialysis are not predictive of dietary compliance. J Am Diet Assoc 2004, 104(1):35-41.

33. Sullivan JF, Eisenstein AB: Ascorbic acid depletion during hemodialysis. JAMA 1972, 220(13):1697-1699.

34. Finkelstein FO, Juergenson $P$, Wang $S$, Santacroce $S$, Levine $M$, Kotanko $P$, Levin NW, Handelman GJ: Hemoglobin and plasma vitamin C levels in patients on peritoneal dialysis. Perit Dial Int 2011, 31(1):74-9.

35. Deicher R, Ziai F, Habicht A, Bieglmayer C, Schillinger M, Horl WH: Vitamin $\mathrm{C}$ plasma level and response to erythropoietin in patients on maintenance haemodialysis. Nephrol Dial Transplant 2004, 19(9):2319-2324.

36. Mezzano D, Pais EO, Aranda E, Panes O, Downey P, Ortiz M, Tagle R, Gonzalez F, Quiroga T, Caceres MS, et al: Inflammation, not hyperhomocysteinemia, is related to oxidative stress and hemostatic and endothelial dysfunction in uremia. Kidney Int 2001, 60(5):1844-1850. 
37. Cross JM, Donald AE, Nuttall SL, Deanfield JE, Woolfson RG, Macallister RJ: Vitamin C improves resistance but not conduit artery endothelial function in patients with chronic renal failure. Kidney Int 2003, 63(4):1433-1442.

38. Kamgar M, Zaldivar F, Vaziri ND, Pahl MV: Antioxidant therapy does not ameliorate oxidative stress and inflammation in patients with end-stage renal disease. J Natl Med Assoc 2009, 101(4):336-344.

39. Fumeron C, Nguyen-Khoa T, Saltiel C, Kebede M, Buisson C, Drueke TB, Lacour B, Massy ZA: Effects of oral vitamin C supplementation on oxidative stress and inflammation status in haemodialysis patients. Nephrol Dial Transplant 2005, 20(9):1874-1879.

40. Chertow GM, Ackert K, Lew NL, Lazarus JM, Lowrie EG: Prealbumin is as important as albumin in the nutritional assessment of hemodialysis patients. Kidney Int 2000, 58(6):2512-2517.

41. Spiekerman AM: Proteins used in nutritional assessment. Clin Lab Med 1993, 13(2):353-369.

42. Myron JA, Merlini G, Sheldon J, Ichihara K: Clinical indications for plasma protein assays: transthyretin (prealbumin) in inflammation and malnutrition. Clin Chem Lab Med 2007, 45(3):419-426.

43. Lee EJ, Myint CC, Tay ME, Yusuf N, Ong CN: Serum ascorbic acid and protein calorie malnutrition in continuous ambulatory peritoneal dialysis patients. Adv Perit Dial 2001, 17:219-222.

44. Fehrman-Ekholm I, Lotsander A, Logan K, Dunge D, Odar-Cederlof I, Kallner A: Concentrations of vitamin C, vitamin B12 and folic acid in patients treated with hemodialysis and on-line hemodiafiltration or hemofiltration. Scand J Urol Nephrol 2008, 42(1):74-80.

45. Pedrini LA, De Cristofaro V, Comelli M, Casino FG, Prencipe M, Baroni A, Campolo G, Manzoni C, Coli L, Ruggiero P, et al: Long-term effects of high-efficiency on-line haemodiafiltration on uraemic toxicity. A multicentre prospective randomized study. Nephrol Dial Transplant 2011.

46. Carracedo J, Merino A, Nogueras S, Carretero D, Berdud I, Ramirez R, Tetta C, Rodriguez M, Martin-Malo A, Aljama P: On-line hemodiafiltration reduces the proinflammatory CD14+CD16+ monocyte-derived dendritic cells: A prospective, crossover study. J Am Soc Nephrol 2006, 17(8):2315-2321.

\section{Pre-publication history}

The pre-publication history for this paper can be accessed here: http://www.biomedcentral.com/1471-2369/12/18/prepub

doi:10.1186/1471-2369-12-18

Cite this article as: Zhang et al:: Low levels of vitamin $C$ in dialysis patients is associated with decreased prealbumin and increased Creactive protein. BMC Nephrology 2011 12:18.

\section{Submit your next manuscript to BioMed Central and take full advantage of:}

- Convenient online submission

- Thorough peer review

- No space constraints or color figure charges

- Immediate publication on acceptance

- Inclusion in PubMed, CAS, Scopus and Google Scholar

- Research which is freely available for redistribution

Submit your manuscript at www.biomedcentral.com/submit
Biomed Central 